\section{NOTE}

\title{
Abiotrophia balaenopterae sp. nov., isolated from the minke whale (Balaenoptera acutorostrata)
}

\author{
Paul A. Lawson, ${ }^{1}$ Geoffrey Foster, ${ }^{2}$ Enevold Falsen, ${ }^{3}$ Berit Sjödén ${ }^{3}$ \\ and Matthew D. Collins ${ }^{1}$
}

\begin{abstract}
Author for correspondence: Matthew D. Collins. Tel: +44 118935 7000. Fax: +441189267917. e-mail: david.collins@bbsrc.ac.uk
\end{abstract}

\footnotetext{
1 Department of Microbiology, BBSRC Institute of Food Research, Reading Laboratory, Reading RG6 6BZ, UK

2 SAC Veterinary Services, Inverness IV2 4JZ, UK

3 Culture Collection, Department of Clinical Bacteriology, University of Göteborg, S-41346 Goteborg, Sweden
}

\begin{abstract}
Phenotypic and phylogenetic studies were performed on a hitherto undescribed micro-organism isolated from a minke whale (Balaenoptera acutorostrata). Comparative 165 rRNA gene sequencing studies demonstrated that the unknown strain constituted a new subline close to, but distinct from, Abiotrophia adiacens and Abiotrophia elegans. The unknown bacterium was readily distinguished from these two Abiotrophia species by biochemical tests and electrophoretic analysis of whole-cell proteins. On the basis of phylogenetic and phenotypic evidence, it is proposed that the unknown bacterium be classified as Abiotrophia balaenopterae sp. nov., the type strain of which is M1975/96/1' (= CCUG 37380').
\end{abstract}

Keywords: Abiotrophia balaenopterae sp. nov., phylogeny, taxonomy, 16S rRNA
Until recently, the genus Abiotrophia included two species, Abiotrophia adiacens and Abiotrophia defectiva (Kawamura et al., 1995). These organisms were originally described by Frenkel \& Hirsch (1961) as a new type of viridans-group streptococci that exhibited satellitism around the colonies of other bacteria. Historically, these bacteria have been referred to by a variety of terms, such as nutritionally variant streptococci (Cooksey et al., 1979) and pyridoxal-dependent streptococci (Roberts et al., 1979), because of their fastidious nutritional requirements. Bouvet et al. (1989) showed the presence of two distinct genetic populations amongst the nutritionally variant streptococci by using DNA-DNA pairing and named the species Streptococcus adjacens and Streptococcus defectivus. Subsequent $16 \mathrm{~S}$ rRNA sequencing studies by Kawamura et al. (1995) showed that $S$. adjacens and $S$. defectivus were phylogenetically remote from authentic streptococci and these authors proposed the genus Abiotrophia to accommodate these species. Recently, a third species of the genus, Abiotrophia elegans, was described from a patient with endocarditis (Roggenkamp et al., 1998).

Abiotrophiae colonize the oral cavity and are residents of the human intestinal and genitourinary tracts (Ruoff, 1991). They cause sepsis and bacteraemia and

The GenBank accession number for the 16S rRNA gene sequence of strain CCUG $37380^{\top}$ is $\mathrm{Y} 16547$. are responsible for a significant proportion of cases of infective endocarditis (Bouvet, 1995; Roberts et al., 1979). The identification of Abiotrophia spp. and related organisms is often problematic. They usually grow poorly in media used routinely for streptococci, e.g. blood agar, and usually require supplements such as pyridoxal. In addition to their fastidiousness, aberrant morphological and staining characteristics and atypical biochemical characteristics further complicate their recognition and reliable identification. $A$. adiacens and $A$. defectiva are, however, phylogenetically very distinct species and possess highly characteristic 16S rRNA genes (Kawamura et al., 1995). Ohara-Nemoto et al. (1997) recently reported the use of this marker as a reliable means for identifying $A$. adiacens and $A$. defectiva. In the course of a study of Gram-positive, catalase-negative cocci associated with sea mammals, 16S rRNA gene sequencing has been used to characterize a hitherto unknown Abiotrophia-like bacterium phylogenetically. On the basis of the results of a polyphasic taxonomic study, a new species, Abiotrophia balaenopterae sp. nov., is described.

Strain M1975/96/1 ${ }^{\mathbf{T}}$ was isolated following a postmortem examination from a minke whale beached on the north-western coast of Scotland. The unknown coccus was recovered as part of the dominant flora of a mixed culture from a 'heavy growth' found within the lungs of the whale, as well as being recovered in 
mixed culture from the spleen. The organism was the sole isolate from both the liver and kidneys. It was, however, not possible to draw conclusions regarding the possible clinical significance of the unknown isolate. The strain has been deposited in the Culture Collection of the University of Göteborg (CCUG) Sweden under the collection number CCUG $37380^{\mathrm{T}}$.

The unidentified organism was cultured on Columbia agar supplemented with $5 \%$ defibrinated horse blood (Oxoid; catalogue no. P0122A) at $37^{\circ} \mathrm{C}$ in air plus $5 \%$ $\mathrm{CO}_{2}$. The strain was characterized biochemically by using the API Rapid ID32S and API ZYM systems according to the manufacturer's instructions (bioMérieux). PAGE analysis of whole-cell proteins was performed as described by Pot et al. (1994). For densitometric analysis, normalization and interpretation of protein patterns the GELCOMPAR GCW 3.0 software package (Applied Maths) was used. The cell wall murein structure and $\mathrm{G}+\mathrm{C}$ content of DNA of strain CCUG $37380^{\mathrm{T}}$ were determined as described by Schleifer \& Kandler (1972) and Garvie (1978), respectively. The 16S rRNA genes of the isolate were amplified by PCR and sequenced directly by using a Taq dye-Deoxy terminator cycle sequencing kit (ABI) and an automatic DNA sequencer (model 373A; ABI). The closest known relatives of the new isolate were determined by performing database searches. These sequences and those of other known related strains were retrieved from GenBank or the Ribosomal Database Project (RDP) library and aligned with the newly determined sequence by using the program PILEUP (Devereux et al., 1984). The resulting multiple sequence alignment was corrected manually and a distance matrix was calculated by using the programs PRETTY and DNADIST (using the Kimura-2 correction parameter) (Felsenstein, 1989). A phylogenetic tree was constructed according to the neighbour-joining method with the program NEIGHBOR (Felsenstein, 1989). The stability of the groupings was estimated by bootstrap analysis (500 replications) with the programs DNABOOT, DNADIST, NEIGHBOR and CONSENSE (Felsenstein, 1989).

The unknown bacterium from minke whale was a Gram-positive coccus that occurred as single cells, in pairs or in short chains. The isolate was catalasenegative, facultatively anaerobic and produced small pinhead colonies on Columbia agar supplemented with $5 \%$ horse blood grown at $37{ }^{\circ} \mathrm{C}$ in air plus $5 \%$ $\mathrm{CO}_{2}$. Neither the addition of pyridoxal to the blood agar nor satellitism was required to support growth. The strain was non-haemolytic. The isolate produced acid from glucose, maltose, pullulan and trehalose. Acid was not produced from D-arabitol, L-arabinose, cyclodextrin, glycogen, lactose, mannitol, melibiose, melezitose, methyl $\beta$-D-glucopyranoside, D-raffinose, D-ribose, sorbitol, sucrose, tagatose or D-xylose. With the commercial API systems, the isolate showed $\mathrm{N}$ acetylglucosaminidase, arginine dihydrolase, ester lipase $\left(\mathrm{C}_{8}\right)$, leucine arylamidase, pyroglutamic acid arylamidase (weak reaction) and urease (weak re-

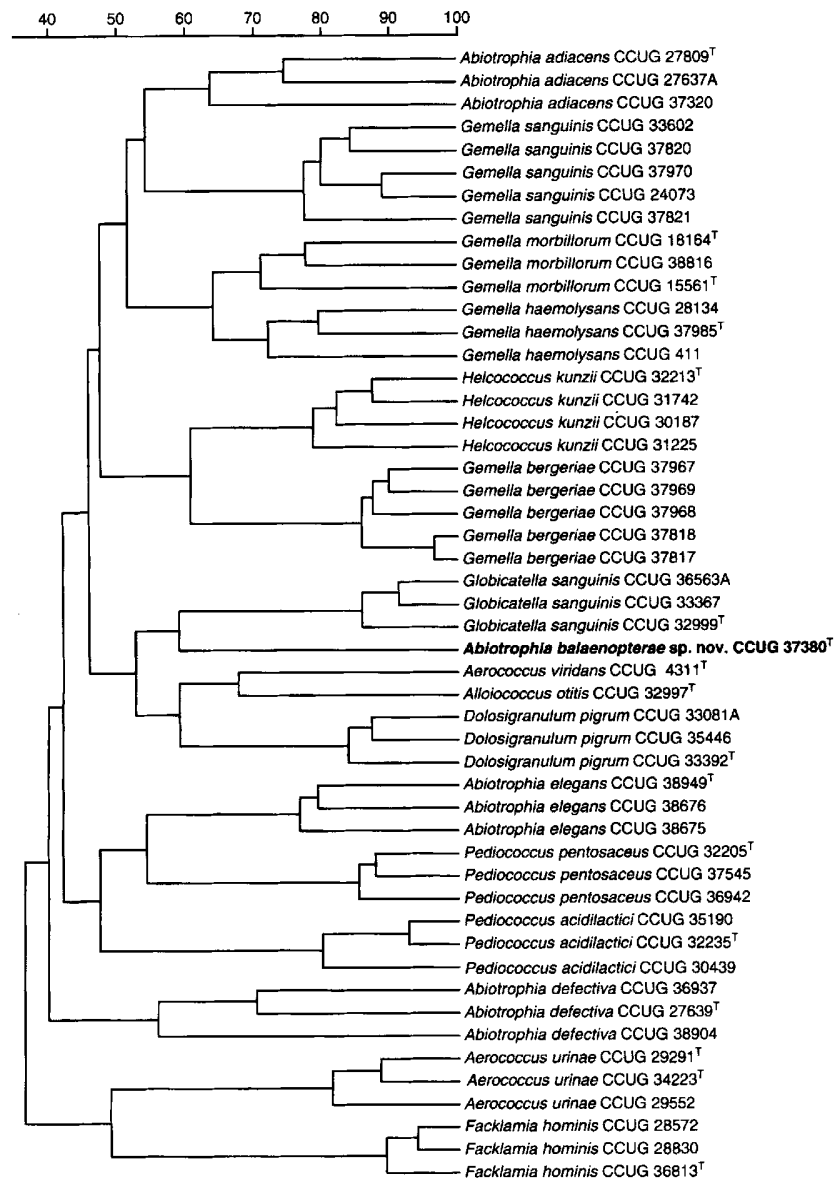

Fig. 1. Similarity dendogram based on whole-cell protein pattern of Abiotrophia balaenopterae sp. nov. and related species. Levels of correlation are expressed as percentage similarities for convenience. Duplicate type strains of Gemella morbillorum and Aerococcus urinae held by CCUG are shown.

action) activities. No activity of acid phosphatase, alkaline phosphatase, alanyl-phenylalanine-proline arylamidase, $\alpha$-galactosidase, $\beta$-galactosidase, $\beta$-galacturonidase, $\alpha$-glucosidase, $\beta$-glucosidase, $\beta$-glucuronidase, glycyl-tryptophan arylamidase, $\beta$-mannosidase, chymotrypsin, $\alpha$-fucosidase or pyrazinamidase was detected. Aesculin was hydrolysed but hippurate and gelatin were not. The isolate did not reduce nitrate and acetoin was not produced. PAGE analysis of wholecell proteins showed the unknown isolate to be separate from all other Gram-positive, catalase-negative reference organisms examined, including Abiotrophia spp., Carnobacterium spp., Facklamia hominis and Globicatella sanguinis (Fig. 1). Strain CCUG $37380^{\mathrm{T}}$ possessed a murein based on L-Orn-D-Asp (type $\mathrm{A} 4 \beta$ ) (nomenclature of Schleifer \& Kandler, 1972 ) and a DNA G + C content of $37 \mathrm{~mol} \%$. In order to assess the genealogical affinity between the unknown organism and other Gram-positive, catalase-negative taxa, comparative 16S rRNA gene sequence analyses were performed. The almost complete gene sequence ( $>1400$ nucleotides) of the unknown coccus was 


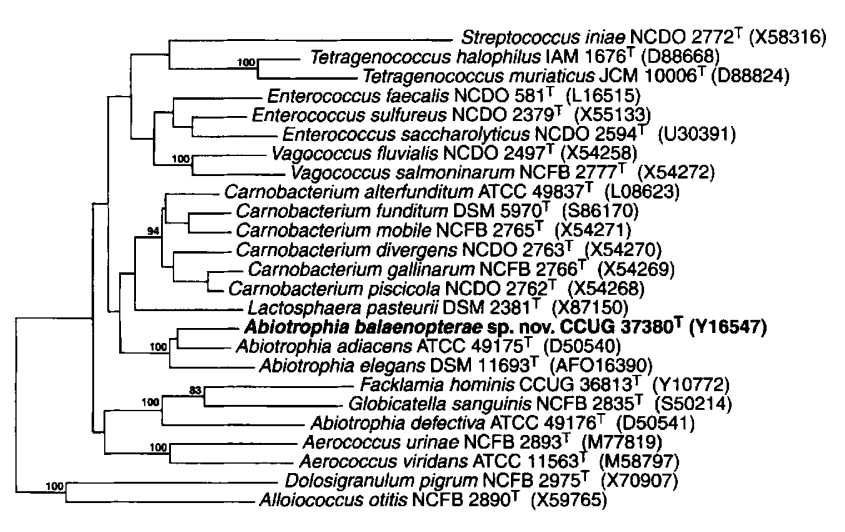

Fig. 2. Unrooted tree showing the phylogenetic relationships of Abiotrophia balaenopterae sp. nov. and some other low $\mathrm{G}+\mathrm{C}$ content, Gram-positive bacteria. The tree, constructed by using the neighbour-joining method, was based on a comparison of approx. 1320 nucleotides. Bootstrap values, expressed as a percentage of 500 replications, are given at branching points.

determined. Sequence searches of GenBank and RDP libraries revealed that the unknown bacterium was associated most closely phylogenetically with the lactic acid group of bacteria. A tree, constructed by neighbour-joining, depicting the phylogenetic affinity of the unknown coccus is shown in Fig. 2. From the treeing analysis, it was evident that the closest relatives of the unknown coccus were $A$. adiacens and $A$. elegans. Pairwise comparisons showed that the $16 \mathrm{~S}$ rRNA of the unknown organism contained 56 and 72 differences (based on 1370 positions) from $A$. adiacens and $A$. elegans, respectively, corresponding to $>3 \%$ sequence divergence.

The unknown isolate from the minke whale clearly belongs to a hitherto unrecognized, Gram-positive, catalase-negative species within the lactic acid group of bacteria. From the 16S rRNA sequence analysis, it is evident that the coccus has a close phylogenetic relationship with $A$. adiacens and $A$. elegans. Sequence divergence values of approx. 3.5 and $5 \%$, respectively, from these two species demonstrate, however, that this relationship is that of phylogenetically closely related, but nevertheless quite separate, species. Support for the separate specific status of the unknown bacterium from minke whale comes from its possession of an $\mathrm{L}-$ Orn-D-Asp-based, directly cross-linked murein (type $\mathrm{A} 4 \beta$ ). This was an unexpected finding, as this murein structure is very unusual among coccus-shaped taxa and has, to our knowledge, been described only for Sporosarcina halophila and Peptococcus glycinophilus. This trait not only distinguishes the unknown bacterium from previously described Abiotrophia species, but also from all other low $\mathrm{G}+\mathrm{C}$-content lactic acid bacteria. Examples of characteristics which serve to distinguish the unknown coccus from $A$. adiacens, $A$. defectiva and A. elegans are outlined in Table 1.

\section{Description of Abiotrophia balaenopterae sp. nov.}

Abiotrophia balaenopterae (bal.aen.op'ter.ae. M.L. fem. n. balaenopterae pertaining to minke whale, Balaenoptera acutorostrata, from which the organism was isolated).

Cells are Gram-positive cocci occurring as single cells, in pairs or in short chains. Cells are non-spore-forming and non-motile. Tiny colonies up to $0.2 \mathrm{~mm}$ in diameter are formed on Columbia agar supplemented with $5 \%$ horse blood at $37^{\circ} \mathrm{C}$. Neither pyridoxal hydrochloride nor satellitism is required to support growth. Haemolysis is not observed. Facultatively anaerobic and catalase-negative. Acid is produced from glucose, maltose, pullulan and trehalose. Acid is not produced from L-arabinose, D-arabitol, cyclodextrin, glycogen, lactose, mannitol, melibiose, melezitose, D-raffinose, D-ribose, sucrose, sorbitol, tagatose or D-xylose. Arginine dihydrolase, pyroglutamic

Table 1. Characteristics that differentiate $A$. balaenopterae sp. nov. from $A$. adiacens, $A$. defectiva and A. elegans

\begin{tabular}{|c|c|c|c|c|}
\hline Character & A. balaenopterae & A. defectiva & A. adiacens & A. elegans \\
\hline \multicolumn{5}{|l|}{ Production of acid from: } \\
\hline Pullulan & + & $\mathrm{V}$ & - & - \\
\hline Sucrose & - & + & + & + \\
\hline Tagatose & - & - & + & - \\
\hline Trehalose & + & $\mathrm{v}$ & - & - \\
\hline \multicolumn{5}{|l|}{ Hydrolysis of: } \\
\hline Hippurate & - & - & - & $\mathrm{V}$ \\
\hline \multicolumn{5}{|l|}{ Production of: } \\
\hline Arginine dihydrolase & + & - & - & + \\
\hline$\alpha$-Galactosidase & - & + & - & - \\
\hline$\beta$-Glucuronidase & - & - & + & - \\
\hline Murein type & $\mathrm{A} 4 \beta$ & $\mathrm{A} 1 \alpha$ & $\mathrm{A} 3 \alpha$ & ND \\
\hline
\end{tabular}

$\mathrm{v}$, Variable; ND, not determined. 
acid arylamidase (weak reaction), $\mathrm{N}$-acetylglucosaminidase, ester lipase $\left(\mathrm{C}_{8}\right)$, leucine arylamidase and urease (weak reaction) activity is detected. Alkaline phosphatase, acid phosphatase, alanyl-phenylalanineproline arylamidase, $\alpha$-galactosidase, $\beta$-galactosidase, $\beta$-galacturonidase, $\beta$-glucuronidase, glycyl-tryptophan arylamidase, $\alpha$-mannosidase, $\beta$-mannosidase, chymotrypsin, trypsin, $\alpha$-fucosidase and pyrazinamidase activity is not detected. Aesculin is hydrolysed. Hippurate and gelatin are not hydrolysed. Nitrate is not reduced. The cell wall contains an L-Orn-D-Aspbased, directly cross-linked murein (type A4 $\beta$ ). The $\mathrm{G}+\mathrm{C}$ content of DNA of the type strain is $37 \mathrm{~mol} \%$ $\left(T_{\mathrm{m}}\right)$. As determined by $16 \mathrm{~S}$ rRNA gene sequence analysis, the new species belongs to the lactic acid group of bacteria with low DNA G $+\mathrm{C}$ contents, and is phylogenetically closely related to $A$. adiacens and $A$. elegans, but may be distinguished from the latter two species using traits shown in Table 1. Isolated from minke whale. Habitat not known. The type strain is CCUG $37380^{\mathrm{T}}$.

\section{Acknowledgements}

This work was supported in part by a grant from the European Union BI02-CT94-3098.

\section{References}

Bouvet, A. (1995). Human endocarditis due to nutritionally variant streptococci: Streptococcus adjacens and Streptococcus defectivus. Eur Heart $J$ 16, 24-27.

Bouvet, A., Grimont, F. \& Grimont, P. A. D. (1989). Streptococcus defectivus sp. nov. and Streptococcus adjacens sp. nov., nutritionally variant streptococci from human clinical specimens. Int J Syst Bacteriol 39, 290-294.

Cooksey, R. C., Thompson, F. S. \& Facklam, R. R. (1979). Physiological characterization of nutritionally variant streptococci. $J$ Clin Microbiol 10, 326-330.
Devereux, J., Haeberli, P. \& Smithies, O. (1984). A comprehensive set of sequence analysis programs for the VAX. Nucleic Acids Res 12, 387-395.

Felsenstein, J. (1989). PHYLIP - Phylogeny inference package (version 3.2). Cladistics 5, 164-166.

Frenkel, A. \& Hirsch, W. (1961). Spontaneous development of L forms of streptococci requiring secretions of other bacteria or sulphydryl compounds for normal growth. Nature 191, 728-730.

Garvie, E. I. (1978). Streptococcus raffinolactis (Orla-Jensen and Hansen); a group $\mathrm{N}$ streptococcus found in raw milk. Int $J$ Syst Bacteriol 28, 190-193.

Kawamura, Y., Hou, X.-G., Sultana, F., Liu, S., Yamamoto, H. \& Ezaki, T. (1995). Transfer of Streptococcus adjacens and Streptococcus defectivus to Abiotrophia gen. nov. as Abiotrophia adiacens comb. nov. and Abiotrophia defectiva comb. nov., respectively. Int J Syst Bacteriol 45, 798-803.

Ohara-Nemoto, Y., Tajika, S., Sasaki, M. \& Kaneko, M. (1997). Identification of Abiotrophia adiacens and Abiotrophia defectiva by $16 \mathrm{~S}$ rRNA gene PCR and restriction fragment length polymorphism analysis. J Clin Microbiol 35, 2458-2463.

Pot, B., Vandamme, P. \& Kersters, K. (1994). Analysis of electrophoretic whole-organism protein fingerprints. In Modern Microbial Methods. Chemical Methods in Prokaryotic Systematics, pp. 493-521. Edited by M. Goodfellow \& A. G. O'Donnell. Chichester: Wiley.

Roberts, R. B., Krieger, A. G., Schiller, N. L. \& Gross, K. C. (1979). Viridans streptococcal endocarditis: the role of various species, including pyridoxal-dependent streptococci. Rev Infect Dis 1, 955-966.

Roggenkamp, A., Abele-Horn, M., Trebesius, K. H., Tretter, U., Autenrieth, I. B. \& Heesemann, J. (1998). Abiotrophia elegans sp. nov., a possible pathogen in patients with culture-negative endocarditis. J Clin Microbiol 36, 100-104.

Ruoff, K. L. (1991). Nutritionally variant streptococci. Clin Microbiol Rev 4, 184-190.

Schleifer, K. H. \& Kandler, O. (1972). Peptidoglycan types of bacterial cell walls and their taxonomic implications. Bacteriol Rev 36, 407-477. 